\title{
Deep water vegetations of Lobophora variegata (Phaeophyceae) in the coral reef of Curaçao: population dynamics in relation to mass mortality of the sea urchin Diadema antillarum
}

\author{
E. D. de Ruyter van Steveninck \& A. M. Breeman \\ Department of Marine Biology, University of Groningen, PO Box 14,9750 AA Haren (Gn), The Netherlands
}

\begin{abstract}
Cover, blade size, growth rate, longevity and reproduction of the foliose brown macroalga Lobophora variegata (Lamouroux) Womersley were recorded in 2 deep-water populations (25 to $35 \mathrm{~m}$ ) in the coral reef of Curaçao (Netherlands Antilles) for over a year. No seasonal effects were observed. Although mean cover was relatively constant, turnover rates were very high with half-life of blades being, on average, only ca $20 \mathrm{~d}$. During this study the herbivorous sea urchin Diadema antillarum Philippi suffered mass mortality. The effect of the disappearance of this grazer was evident at one of the 2 locations, where $D$. antillarum densities had been highest, $L$. variegata cover lowest and blade sizes smallest. At this station, following $D$. antillarum mortality, cover and blade size increased significantly and reached a new equilibrium after ca 6 mo.
\end{abstract}

\section{INTRODUCTIOTN}

Fleshy and filamentous algae are generally inconspicuous on coral reefs (reviews by Ogden \& Lobel 1978, Borowitzka 1981, Gaines \& Lubchenco 1982, Littler \& Littler 1984), although dense macroalgal vegetation is often found in shallow intertidal reefs and wave-washed reef parts (e.g. Randall 1961, van den Hoek et al. 1975, 1978, Ogden 1976, Adey et al. 1977, Hatcher 1981, Hay 1981). Deep reef zones may also bear conspicuous algal vegetation (van den Hoek et al. 1978, Hay 1981, Littler \& Littler 1984, Morrison 1984b). In these cases, reduced grazing seems to be the main factor allowing the development of macroalgae.

Lobophora variegata (Lamouroux) Womersley (syn. Pocockiella variegata [Lamouroux] Papenfuss), a brown, foliose macroalga with a worldwide distribution in tropical to warm temperate seas (cf. Earle 1969, Stephenson \& Stephenson 1972), has been reported from many Caribbean and Indo-Pacific reefs. In Curaçao, Netherlands Antilles, van den Hoek et al. (1978) found this species forming distinct belts in the deep algal community ( $>30 \mathrm{~m}$ depth) as well as in the eulittoral community, whereas it was absent in the intermediate reef zones. This discontinuous depth range has been attributed to intensive grazing in the areas devoid of $L$. variegata (van den Hoek et al. 1978).

Studies on (sub)tropical, subtidal macroalgae have shown seasonal changes in growth, abundance and reproduction for several species (reviewed by Morrison 1984a), but so far, no extensive ecological study has been carried out on algal species occurring in the deeper zones of coral reefs. Yet, this kind of study is essential if spatial and temporal distribution patterns of algae in coral reefs are to be understood (Littler \& Littler 1984).

In the present study 2 deep-water populations $(>25 \mathrm{~m})$ of Lobophora variegata, from 2 locations at Curaçao differing in visual $L$. variegata cover and in densities of the herbivorous sea urchin Diadema antillarum Philippi, were monitored for over a year. Cover, blade size, growth rate, longevity and presence of sporangia were recorded. The results are interpreted in relation to the disappearance of the $D$. antillarum population, which suffered mass mortality in the course of this investigation (Bak et al. 1984, de Ruyter van Steveninck \& Bak 1986). All through 1984 and $1985 \mathrm{D}$. antillarum remained virtually absent from the coral reef of Curaçao (Table 1). 


\section{MATERIAL AND METHODS}

Location. This study was carried out in the coral reef off the leeward southwest coast of Curaçao (Netherlands Antilles) between February 1983 and February 1985 (Fig. 1). For a general description of the area see

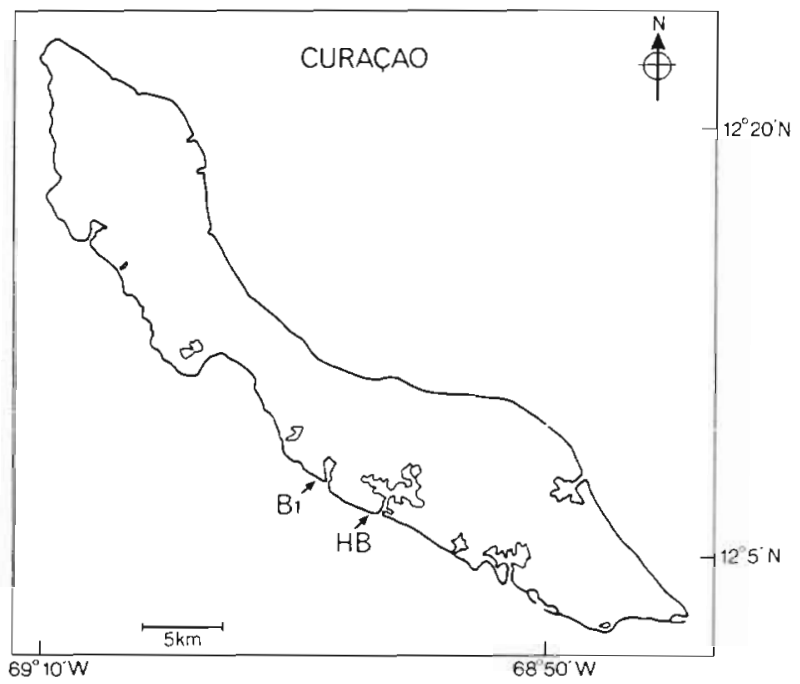

Fig. 1. Map of Curaçao (Netherlands Antilles) showing the 2 locations. HB: reef in front of the Holiday Beach Hotel; B1: CARMABI Buoy 1, in front of Klein Piscadera

van den Hoek et al. (1975). In the period of investigation mean monthly water temperatures at $30 \mathrm{~m}$ depth fluctuated between 25.9 and $28.1^{\circ} \mathrm{C}$ (Fig. 2). Global radiation ranged from 358 to $572 \mathrm{cal} \mathrm{cm}^{-2} \mathrm{~d}^{-1}$ (Fig. 2). In February 1983, 2 locations (Fig. 1) were selected in the deep reef zone (ca 25 to $35 \mathrm{~m}$ ) which strongly differed in visual Lobophora variegata cover and in the density of the herbivorous sea urchin Diadema antillarum: (1) the reef in front of the Holiday Beach Hotel (HB), with a dense $L$. variegata vegetation consisting of large frondose plants (Fig. 3) extending from $20 \mathrm{~m}$ downward and high $D$, antillarum densities occurring at shallow depths only (Table 1); and (2) the reef in front of Klein Piscadera, CARMABI Buoy 1 (B1) with a sparse $L$. variegata vegetation consisting of small, more or less crustose plants extending no higher than $25 \mathrm{~m}$ and high $D$. antillarum densities down to 12 to $20 \mathrm{~m}$ depth (Table 1). This was before the occurrence of mass mortality in the $D$. antillarum population, which took place in October 1983 (Bak et al. 1984).

Quadrats. Cover, blade size, growth rate and persistence of Lobophora variegata blades were monitored at monthly intervals over various periods (Table 2). For this purpose, permanent quadrats $(16 \times 11.5 \mathrm{~cm})$ were marked with steel nails in relatively dense $L$. variegata patches. Using a Nikonos underwater camera, equipped with a Nikon close-up lens in combination with a $28 \mathrm{~mm}$ lens and with flashlight, colour slides (Kodak Ektachrome 200 ASA) were made, which were projected with a darkroom enlarger with a $50 \mathrm{~mm}$ lens for further analysis. At first, the quadrats were photographed once every $4 \mathrm{wk}$. However, after some time it became clear that the $L$. variegata vegetation was very dynamic in character: most of the blades having disappeared within a single month. Therefore, new sets of quadrats were selected at both locations, which were photographed more frequently, in principle once every $2 \mathrm{wk}$. This enabled an estimation of blade persistence and growth rates over short periods.

Cover. Lobophora variegata cover was monitored in 4 to 9 permanent quadrats over various periods (Table 2). In order to estimate cover, the slides were projected on a grid with 100 points. Counts were made of points with and without plants present (Littler \& Littler 1985). This gave the percentage L. variegata cover within each quadrat at the various dates. Since blades can overlap (Fig. 3), cover data actually represent the projected area covered by $L$. variegata.

Blade size and growth rate. In order to establish blade size and growth rates of the circular to kidneyshaped Lobophora variegata blades, the 'radius' of the blade was constructed following a standardised method (Fig. 4). This parameter was chosen because in many cases only part of the blade was visible, which

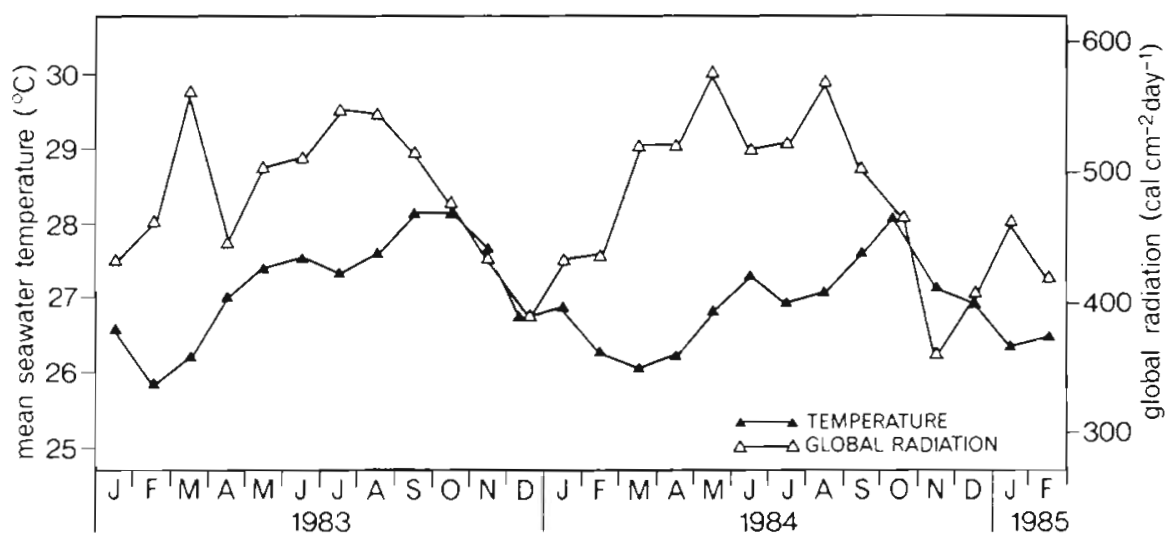

Fig. 2. Mean monthly water temperatures at $30 \mathrm{~m}$ depth (data from CARMABI) and monthly global radiation (Eppley Black \& White Solarimeter, Meteorological Service Curaçao) 


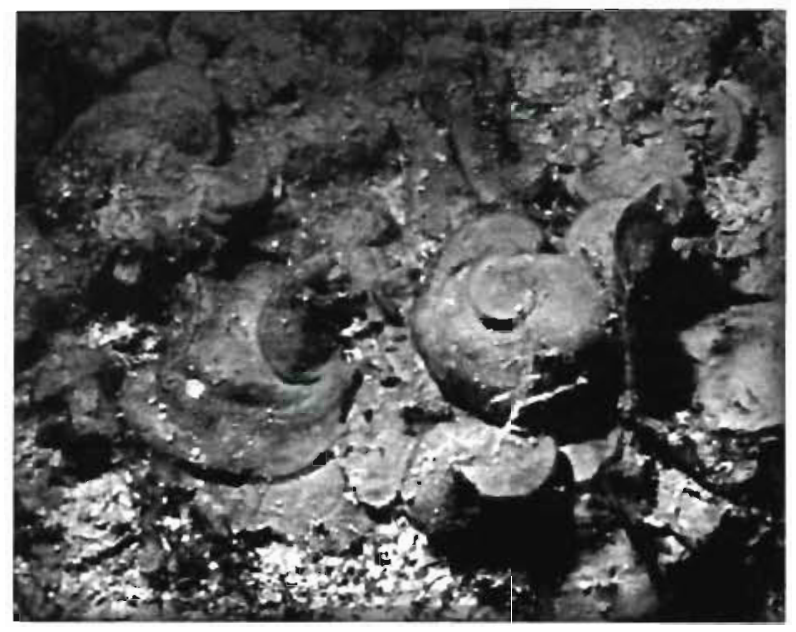

Fig. 3. Lobophora variegata at Holiday Beach, $27 \mathrm{~m}$ depth (Oct 1983), $2 / 3 \times$ natural size
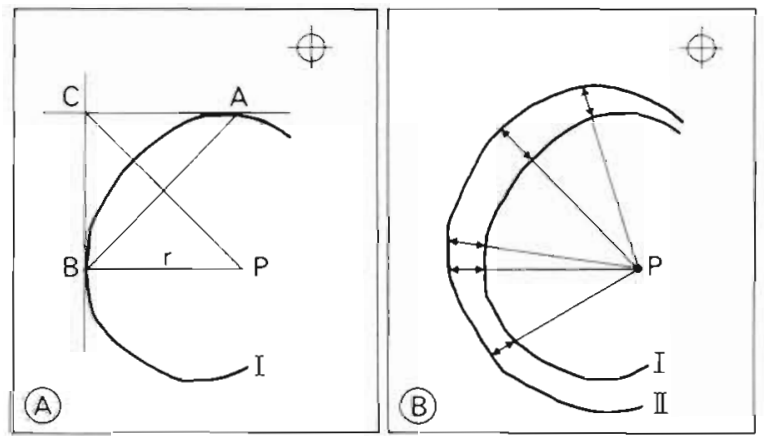

Fig. 4. Lobophora variegata. Parameters for measuring blade size and growth rates on the basis of an estimation of the 'radius' in the circular to kidney-shaped blades. (A) Determination of 'radius' as follows: choose tangent $\mathrm{AC}$ at random; construct tangent $\mathrm{BC}$ perpendicular to $\mathrm{AC}$; construct $\mathrm{CP}=$ $\mathrm{AB}$, where $\mathrm{CP}$ halves the angle $\mathrm{ACB}$; find $\mathrm{P}$ as the 'circle's' central point; find 'radius' $I$. (B) Determination of growth rates: line $\mathrm{I}=$ blade margin at $t=0 ; \mathrm{P}=$ 'circle' $\mathrm{s}$ ' central point at $\mathrm{t}=0$; line $\mathrm{II}=$ blade margin at $\mathrm{t}=\mathrm{x}, 13$ to $22 \mathrm{~d}$ after $t=0$. (NB: PVC reference mark in quadrat ensures correct position.) Find 'radius' enlargement during $t=x-0$ for 5 randomly chosen 'radii' prohibited the measurement of e.g. surface areas. Blade size was estimated monthly in 15 to 30 randomly chosen plants at each location (Table 2). Growth rates were measured monthly over a 13 to $22 \mathrm{~d}$ period as the increase in blade 'radius' during this period. For this purpose, only blades with intact margins were considered (Table 2) as this will give an impression of the actual growth potential of the $L$. variegata blades at the 2 locations in different seasons. Increase in blade 'radius' was consistently logarithmic with time and independent of blade size. Growth was expressed as the Specific Growth Rate (percentage increase per day) defined as:

$$
\text { S.G.R. }=\frac{\ln \left(r_{x} / r_{0}\right)}{t_{x}-t_{0}} \times 100 \%
$$

where $\mathrm{r}_{0}=$ 'radius' at a specific time $\mathrm{t}_{0} ; \mathrm{r}_{\mathrm{x}}=$ 'radius' at a subsequent time $t_{x}$ (Fig. 4).

Persistence of blades. Persistence of the blades was measured as half-lives. In each month, 13 to 30 individual blades were selected on each location and subsequently the presence of these blades was checked at intervals of $2 \mathrm{wk}$ until all blades had disappeared. Depletion curves were constructed (Harper 1977), from which the number of days after which half of the blades had disappeared was calculated for each month.

Reproduction. In order to establish the occurrence of reproduction in the Lobophora variegata populations 14 to 28 plants were sampled unce a month at both locations from outside the quadrats between September 1983 and November 1984. The number of reproductive plants was expressed as a percentage of the total number of blades collected on each sampling date.

Transects at Buoy 1. Changes in the depth distribution of Lobophora variegata during the 16 mo following Diadema antillarum mass mortality were studied in 4 permanent transects over the reef slope between 19 and $41 \mathrm{~m}$ depth at CARMABI Buoy 1 . Surveys were

Table 1. Diadema antillarum (D.a.) and Lobophora variegata (L.v.). Occurrence at various depths at 2 locations before and after D. antillarum mass mortality in October $1983 .++$ : abundant; ++ : patchy $($ L.v. $) ;$ : present; - : absent

\begin{tabular}{|c|c|c|c|c|c|c|c|c|}
\hline \multirow[t]{3}{*}{ Depth $(\mathrm{m})$} & \multicolumn{4}{|c|}{ Before mortality } & \multicolumn{4}{|c|}{2 yг after mortality } \\
\hline & \multicolumn{2}{|c|}{ Holiday Beach } & \multicolumn{2}{|c|}{ CARMABI Buoy 1} & \multicolumn{2}{|c|}{ Holiday Beach } & \multicolumn{2}{|c|}{ CARMABI Buoy 1} \\
\hline & D.a. & L.V. & D.a. & L.V. & D.a. & L.V. & D.a. & L.v. \\
\hline 5 & +++ & - & +++ & - & - & - & - & - \\
\hline 12 & + & - & +++ & - & - & + & - & - \\
\hline 20 & - & +++ & + & - & - & +++ & - & - \\
\hline 25 & - & +++ & + & + & - & +++ & - & ++ \\
\hline 30 & - & $+t+$ & + & + & - & +++ & - & ++ \\
\hline 35 & \multicolumn{2}{|c|}{ No data } & - & ++ & \multicolumn{2}{|c|}{ No data } & - & ++ \\
\hline
\end{tabular}


made in April and October 1984 and in February 1985. In each transect $L$. variegata cover was estimated using the Braun-Blanquet scale within a $1 \mathrm{~m}^{2}$ frame. When 2 or more quadrats in a transect were situated at the same depth, the mean cover from these quadrats was taken for that particular depth.

Statistical analyses. One-way ANOVA was carried out on blade size and specific growth rate data to test for significant variation over time. Random sampling within the quadrats and high turnover rates of individual Lobophora variegata blades provided independence of data over time, thus meeting the requirements of ANOVA (Sokal \& Rohlf 1981). As cover data are not independent over time, 2-way ANOVA without replication, with dates and quadrats as the 2 factors, was used in statistical analysis. If necessary (Tukey's Test for Nonadditivity: Sokal \& Rohlf 1981) data were transformed with logarithmic transformation to meet the assumption of additivity. In cases where an ANOVA revealed significant variation over time the nature of this variation was further analysed in an 'a posteriori' test by the 'Sum of Squares Simultaneous Test Procedure' (SS-STP: Sokal \& Rohlf 1981). In comparisons between 2 sample means 1-way ANOVA or ttests were used. Percentages (cover, specific growth rates) were transformed with the angular transformation (Sokal \& Rohlf 1981). When variances were nonhomogeneous (Cochran's Test of the Equality of several variances: Sachs 1982; F-test: Sokal \& Rohif 1981) the data were properly transformed (see 'Results') before carrying out an ANOVA or t-test. Finally, Spearman's Rank Correlation was applied to analyse possible correlations between 2 variables. When attempting to correlate temperature and light conditions with cover or blade size, mean temperature and light values in the preceding month were used. All statistical tests were considered significant if $p<0.05$.

\section{RESULTS}

Temporal variations in Lobophora variegata cover in the permanent quadrats at Holiday Beach (HB) and CARMABI Buoy 1 (B1) were analysed (Fig. 5a; Table 2). Table 2 lists ANOVA results for the various quadrat sets monitored; Fig. 5a illustrates cover at HB and $\mathrm{B} 1$ during the periods when the maximum number of quadrats was monitored at each location ( 9 and 8 , respectively).

Analyses of variance revealed no significant variation over time at $\mathrm{HB}$ (Table 2), indicating that Lobophora variegata cover did not change seasonally at this station. Variation between quadrats was high: highest cover in one quadrat coincided with low cover in another and vice versa. Also, cover within quadrats

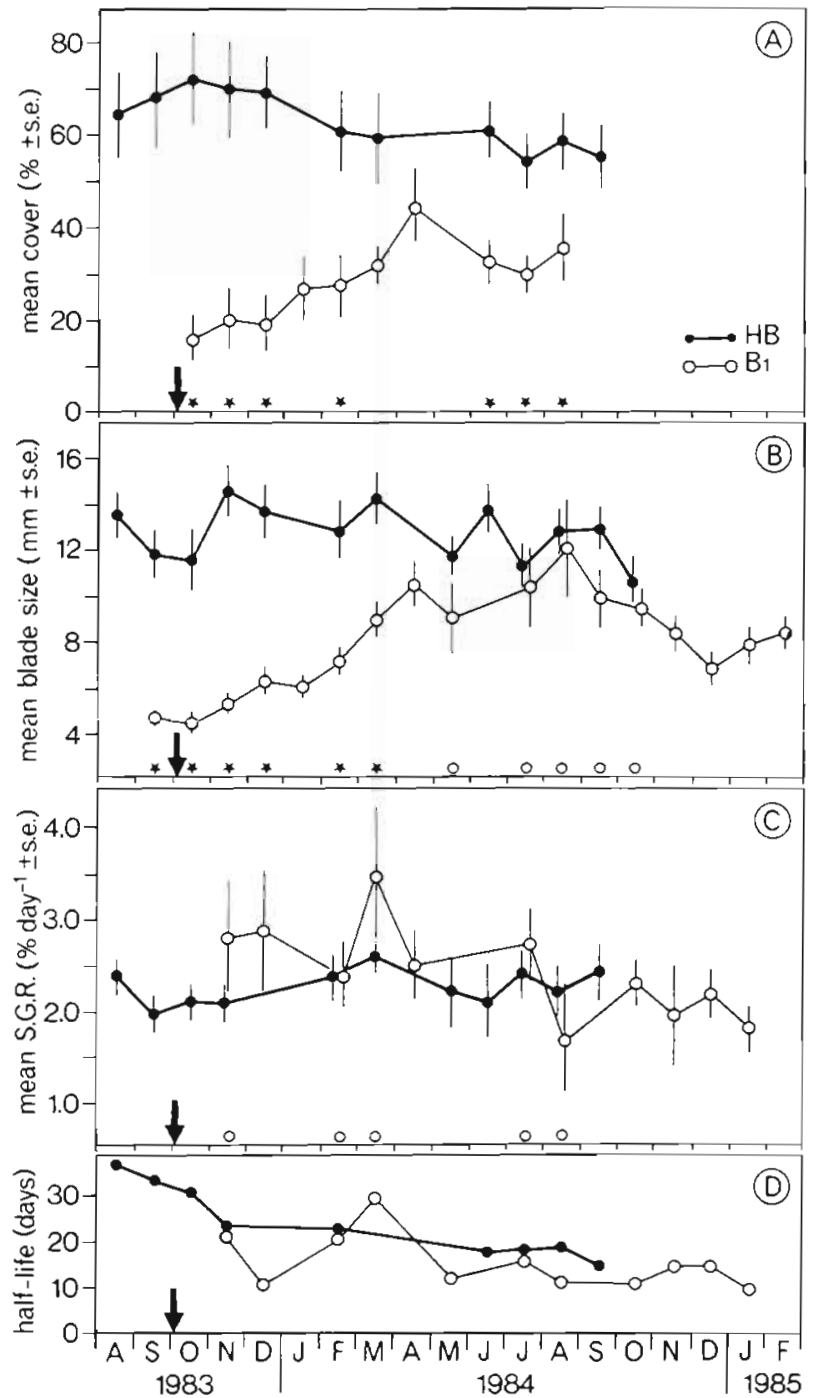

Fig. 5. Lobophora variegata at Holiday Beach (HB) and CARMABI Buoy 1 (B1). (a) Mean percentage cover based on $n=9$ (HB) and $n=8$ (B1) permanent quadrats respectively; (b) mean blade size (as 'radius') based on 15 to 30 plants; (c) mean specific growth rate ( 5 to 24 plants); (d) half-lives (13 to 30 plants). Results of statistical analysis between locations shown on abscissa (1-way ANOVA) $\star p<0.05 ;(O)$ not significant $(\mathrm{p}>0.05)$. Arrow indicates Diadema antillarum mass mortality

fluctuated strongly from less than $10 \%$ to more than $90 \%$ within a single year (Fig. 6).

At Buoy 1 cover was significantly lower than at Holiday Beach (Fig. 5a). Analyses of variance showed significant variation over time at B1 for all sets of quadrats (Table 2). Except for a significant negative correlation with seawater temperature in Quadrats 1 to 4 between February 1983 and August 1984, there were no significant correlations with seawater temperature at $30 \mathrm{~m}$ depth, nor with global radiation in the 3 sets of quadrats monitored (Spearman's Rank Correlation), making 
Table 2. Lobophora variegata. Analysis of temporal variations in cover, blade size and specific growth rate (S.G.R.) at 2 locations. Cover: 2-way ANOVA; blade size and specific growth rate: 1 -way ANOVA. ${ }^{\circ} p<0.05$; ns: not significant $(p>0.05)$

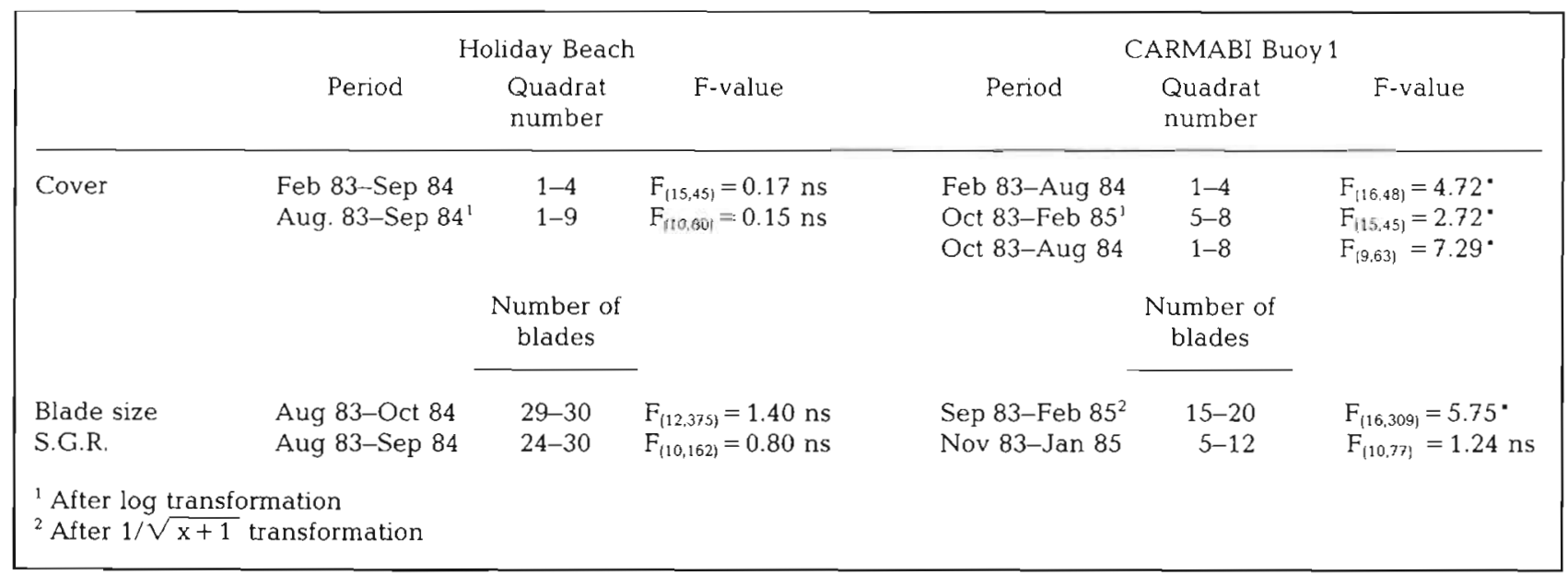

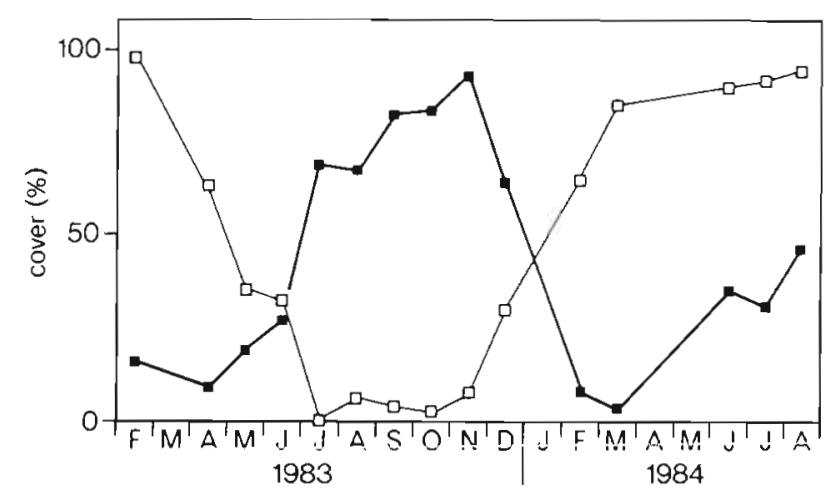

Fig. 6. Lobophora variegata. Cover at Holiday Beach in 2 individual quadrats between Feb 1983 and Aug 1984 to illustrate high variation between and within quadrats

seasonal control of Lobophora variegata cover at B1 very unlikely. Major changes in L. variegata cover occurred between October 1983, when mass mortality of Diadema antillarum occurred, and April 1984 (Fig. 5a). Prior to October 1983 no significant variation over time had been observed (Quadrats 1 to 4 : Feb to Oct 1983 , SS-STP) indicating that there had been an equilibrium in L. variegata cover. Between October 1983 and April 1984 cover increased significantly (Quadrats 1 to 8, SS-STP) to reach a new equilibrium level by April 1984, after which month cover no longer varied over time (Quadrats 1 to 8: to Aug 1984; Quadrats 5 to 8: to Feb 1985, SS-STP).

At HB mean blade size (as 'radius') of Lobophora variegata (Fig. $5 \mathrm{~b}$ ) ranged from $10.4 \mathrm{~mm} \pm 5.5$ (SD) to $14.6 \mathrm{~mm} \pm 6.1, \mathrm{n}=30$, and was fairly constant between August 1983 and October 1984 with no significant annual variations in blade size (Table 2).

At B1 an analysis of variance on blade size revealed significant variation over time (Table 2 ). This may be attributed to a significant (SS-STP) increase between October 1983 (4.4 mm \pm 1.7 [SD], $\mathbf{n}=15)$ and April 1984 (10.4 mm $\pm 3.9, \mathrm{n}=20$ ), the 6 mo immediately after Diadema antillarum mass mortality. No significant correlation with seawater temperature or global radiation was detected. Between April 1984 and February 1985, no significant variation over time was observed (SS-STP), indicating that a new equilibrium level had been established. This trend parallelled that observed in cover (Quadrats 1 to 8; Spearman's Rank Correlationi). About 7 mô after $D$. aniiharun moriaity, the initial difference in mean blade size between Holiday Beach and Buoy 1 had disappeared (Fig. 5b).

Mean specific growth rates of Lobophora variegata blades ranged from $1.97 \% \mathrm{~d}^{-1} \pm 1.02$ (SD), $\mathrm{n}=24$, to $2.59 \% \mathrm{~d}^{-1} \pm 0.67, \mathrm{n}=15$, at $\mathrm{HB}$ and from $1.73 \% \mathrm{~d}^{-1}$ $\pm 1.37, \mathrm{n}=5$, to $3.46 \% \mathrm{~d}^{-1} \pm 2.06, \mathrm{n}=9$, at $\mathrm{B} 1$. There was no significant difference between the 2 locations nor was there a significant variation over time at any of the 2 locations, precluding seasonal control of growth of L. variegata (Fig. 5c; Table 2). Evidently, the increase in cover and blade size at B1 between October 1983 and April 1984 cannot be attributed to increased growth rates.

Turnover rates of Lobophora variegata blades (Fig. 5d) were high at both locations. At HB half-lives ranged from 15 to $39 \mathrm{~d}$ and decreased significantly between August 1983 and 1984 (linear regression), and this was parallelled by a slight, although not significant, decrease in cover (Fig. 5a). During this period, increased sedimentation (de Ruyter van Steveninck pers. obs.) may have been responsible for the decrease in half-lives.

At B1, half of the blades had disappeared within 9 to 29 d. At this station half-lives were significantly higher (20.3 d \pm 7.4 [SD], $\mathrm{n}=4$ ) between November 1983 and 
March 1984, the 5 mo immediately after Diadema antillarum mass mortality, than in the following $10 \mathrm{mo}$ $(12.3 \mathrm{~d} \pm 2.1, \mathrm{n}=7$ ) when cover and mean blade size had also levelled off (t-test on log-transformed data).

Reproductive plants were present during the entire period (Sep 1983 to Oct 1984) at HB (Fig. 7) but relative

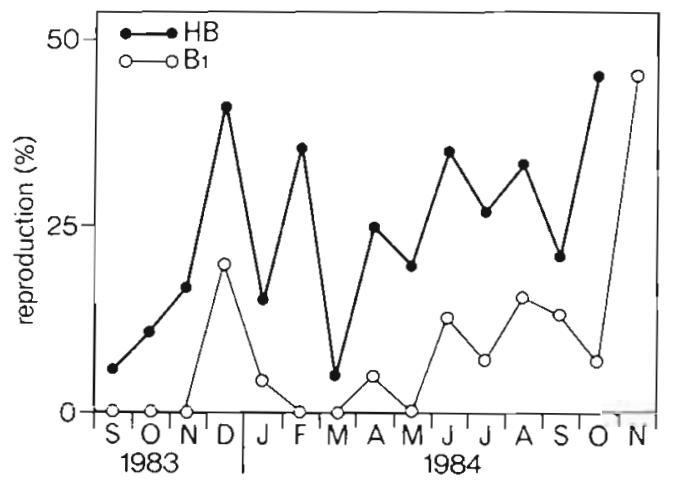

Fig. 7. Lobophora variegata. Percentage of reproductive plants at Holiday Beach (HB) and CARMABI Buoy 1 (B1). $N=$ 14 to 28 blades, sampled at random from ca $30 \mathrm{~m}$ depth outside the permanent quadrats

numbers did not correlate with water temperature at $30 \mathrm{~m}$ nor with global radiation (Spearman's Rank Correlation). At B1, reproductive plants were absent during some months, and again, no correlation with temperature or light was found. However, there was a significant correlation between the fluctuations observed at HB and B1 (Spearman's Rank Correlation) suggesting some external regulating factor.

At B1, the vertical range of Lobophora variegata increased after Diadema antillarum mass mortality. Between April 1984 and February 1985 (Fig. 8), mean vertical range of $L$. variegata over the reef slope expanded from 7.2 to $14.1 \mathrm{~m}$, a 2 -fold increment, and the mean number of quadrats in which it was present in the 4 transects increased significantly from $4.3 \pm 1.3$ to $11.0 \pm 1.2$ (t-test for paired comparisons). However, in quadrats with existing $L$. variegata patches cover did not increase (Fig. 8), which is in agreement with the newly established equilibrium levels in the permanent quadrats after April 1984 (Fig. 5a).

\section{DISCUSSION}

Seasonality in growth, abundance and reproduction in subtidal, (sub)tropical aigae has been observed in green (Bach 1979, O'Neal \& Prince 1982, Morrison 1984a), brown (Umamaheswara Rao 1969, Umamaheswara Rao \& Kalimuthu 1972, Kaliaperumal \& Kalimuthu 1976, Prince \& O'Neal 1979, Prince 1980) and red algae (Rama Rao 1970, Dawes et al. 1974, Josselyn 1977, Hay \& Norris 1984); all, however, inhabiting relatively shallow depths ( $14 \mathrm{~m}$ maximum).

The present study indicates that abundance, size, growth and reproduction of the brown, foliose macroalga Lobophora variegata in the deep coral reef of Curaçao is not significantly influenced by season. At Holiday Beach, a location with a well-developed $L$. variegata vegetation from ca $20 \mathrm{~m}$ downward, no variation over time was demonstrated for cover, blade size and growth rate. In addition, variation in cover be-
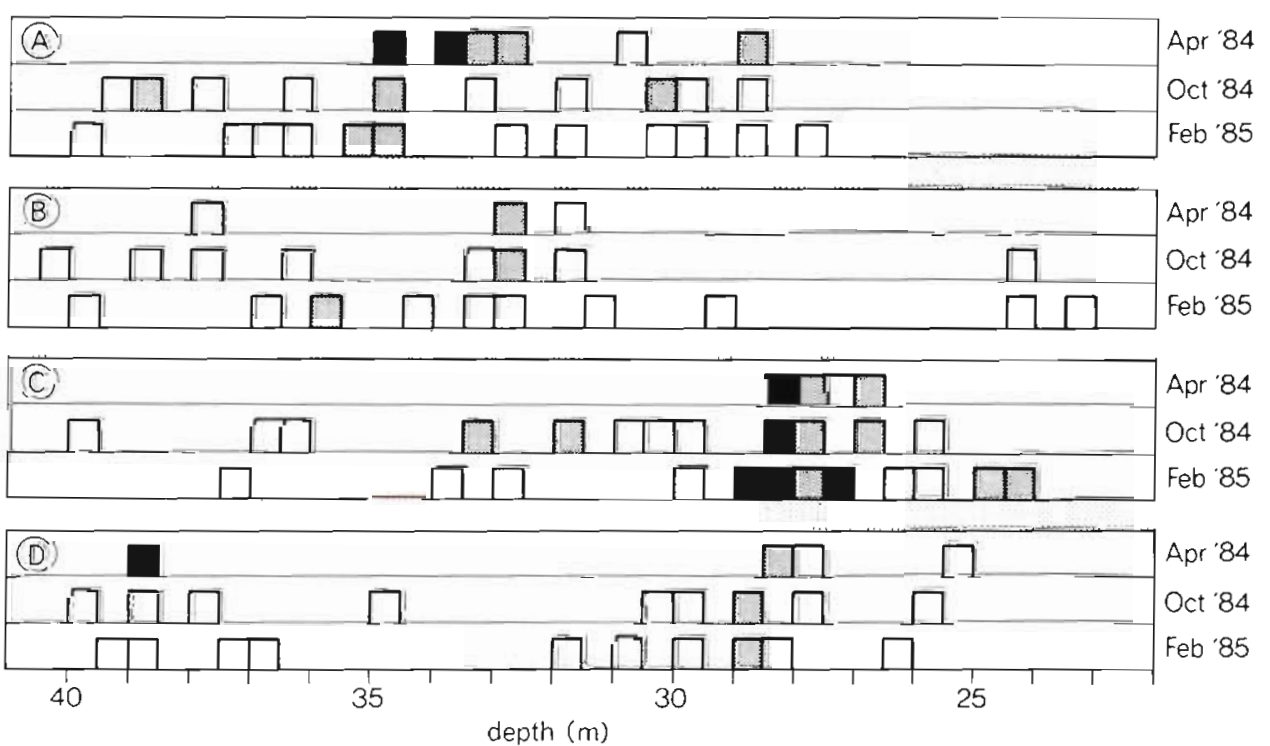

Fig. 8. Lobophora variegata. Changes in depth distribution at CARMABI Buoy 1 as observed in 4 transects between Apr 1984 and Feb 1985. Cover in $1 \mathrm{~m}^{2}$ quadrats estimated using the Braun-Blanquet scale: white, up to $1 \%$; stippled, 1 to $5 \%$; black, 5 to $25 \%$ 
tween quadrats was large (Fig. 6) and peaks in abundance did not coincide for the various quadrats, making seasonal trends unlikely

At Buoy 1, Lobophora variegata formed an indistinct component of the vegetation at $30 \mathrm{~m}$ depth at the start of this investigation, while it was more conspicuous deeper (ca $35 \mathrm{~m}$ ). Mean cover in permanent quadrats between 30 and $35 \mathrm{~m}$ increased significantly in the course of this study. This increase was most prominent between October 1983 and April 1984 and parallelled the same trend in mean blade size. But, as fluctuations in mean growth rate were not significant, and as trends at B1 (with high pre-mortality Diadema antillarum densities) were not parallelled by similar trends at $\mathrm{HB}$ (with low premortality $D$. antillarum densities), we attribute this increase to an effect of $D$. antillarum mass mortality (Bak et al. 1984, de Ruyter van Steveninck \& Bak 1986) rather than to seasonal effects.

Year-round presence of Lobophora variegata has also been reported in other studies (e.g. Bernatowicz 1952, Croley \& Dawes 1970, Tsuda 1972, 1974, Peckol 1982, Peckol \& Searles 1983, 1984), one of which (Tsuda 1972) included a deep coral reef population. In the (sub)tropics, seasonal changes in abundance were observed by Bernatowicz (1952) and Tsuda (1972, 1974), while in collections by Dawes \& Van Breedveld (1969), Tsuda \& Kami (1973) and Mathieson \& Dawes (1975) L. variegata was not represented during part of the year. On the North Carolina continental shelf, where $L$. variegata reaches its northern distribution limit, $L$. variegata showed large seasonal and year-toyear fluctuations in abundance (Peckol \& Searles 1984). The characterization of $L$. variegata as a perennial alga in Florida (Croley \& Dawes 1970) and in North Carolina (Peckol 1982, Peckol \& Searles 1984) is supported by its year-round occurrence at Curaçao. In view of its morphology, however, it is difficult to distinguish individual $L$. variegata plants. The single blades considered in the present study are not perennial, as these had half-life spans of less than a month. But encrusting remnants, which cannot be separated as individuals, probably produce new blades constantly and thus are perennial. The problem of characterizing red and brown crusts with regard to their annual or perennial nature has previously been raised by Sears \& Wilce (1975).

In contrast to North Carolina, where reproductive Lobophora variegata is limited to late spring (Peckol 1982), reproductive $L$. variegata was present the whole year round at Curaçao. The absence of reproductive plants during some months at B1, while they were present at $\mathrm{HB}$, may be a consequence of life spans, which on average were shorter at B1 than at $H B$, preventing plants from becoming fertile.

Comparison of the developments in the Lobophora variegata populations after Diadema antillarum mass mortality (Bak et al. 1984) at the 2 studied locations (Holiday Beach and Buoy1) may explain the differences in $L$. variegata cover that existed between both locations originally. Growth rates at HB are comparable with those at B1 (Fig. 5c), demonstrating that growth itself did not limit $L$ variegata distribution and cover at B1. At first, blades were smaller here, but by May 1984, this difference had disappeared (Fig. 5b). Cover in the quadrats changed similarly, although differences between both locations remained significant (Fig. 5a). Thus, disappearance of $D$. antillarum led to an initial increase of $L$. variegata cover and blade size at B1, which levelled off about 6 mo later to reach new equilibrium levels.

Half-lives of the Lobophora variegata blades concurred with the observed shifts in cover and blade size. Before April 1984 half-lives were significantly higher than thereafter and allowed $L$. variegata to grow longer and thus to reach higher cover and blade size. Higher disappearance rates between May 1984 and January 1985, probably as a consequence of increased grazing by herbivorous fishes (Ogden et al. 1973, Hay \& Taylor 1985), limited further expansion of the $L$. variegata vegetation and a new equilibrium was reached between $L$. variegata cover and grazing. It is interesting that de Ruyter van Steveninck \& Bak (1986) observed the same shift in the abundance of algal turfs: 7 mo after Diadema antillarum mass mortality cover of turf algae at $27 \mathrm{~m}$ depth, at location $B 1$, had reached a new equilibrium level, ca $20 \%$ higher than that in October 1983.

These results and evidence that Lobophora variegata is indeed consumed in considerable quantities by herbivores (Lewis 1985, de Ruyter van Steveninck \& Breeman unpubl.) confirms the hypothesis raised by van den Hoek et al. (1978), that grazing can restrict $L$. variegata distribution. At location $\mathrm{HB}$, with low premortality Diadema antillarum densities in the deep reef $\left(0.4\right.$ and $0.1 \mathrm{~m}^{-2}$ at depths of 12 and $25 \mathrm{~m}$, respectively; Bak et al, 1984, de Ruyter van Steveninck pers. obs.) and relatively high $L$. variegata cover, no effect of the disappearance of $D$. antillarum was observed on cover and blade size of $L$. variegata. At B1, pre-mortality densities of $D$. antillarum were relatively high in the deep reef $\left(2.5\right.$ and $0.4 \mathrm{~m}^{-2}$ at depths of 12 and $25 \mathrm{~m}$, respectively; Bak et al. 1984, de Ruyter van Steveninck pers. obs.) while cover of L. variegata was low. After mortality in October 1983 both cover and blade size increased significantly, while the depth range and frequency of $L$. variegata in the monitored reef transects also increased (Fig. 8). The fact that cover of existing $L$. variegata patches in these transects did not increase is in agreement with the observation that cover within $L$. variegata vegetations had reached a 
new equilibrium level after April 1984 (Fig. 5a). Evidently, this does not mean that $L$. variegata cannot extend its distribution by colonizing newly available substratum. According to Carpenter (1981), D. antillarum can control macroalgal abundance by ingesting germlings and sporelings, thus preventing successional dominance of macroalgae. Possibly spores and torn-off pieces of blades (de Ruyter van Steveninck pers. obs.) have a better chance of becoming established in a situation without grazing by $D$. antillarum. Extension of $L$. variegata at B1, after $D$, antillarum mass mortality, was also reported by de Ruyter van Steveninck \& Bak (1986) and in Jamaica by Morrison (1984b) and Liddel \& Ohlhorst (1986).

The high turnover rates of Lobophora variegata blades (half-lives of 9 to $39 \mathrm{~d}$ ) and the results of grazing experiments (de Ruyter van Steveninck \& Breeman unpubl.) are evidence of heavy grazing pressure on $L$. variegata even after Diadema antillarum mass mortality. Contradictory observations on the susceptibility of L. variegata to various grazers (Earle 1972, Brawley \& Adey 1977, Hay 1981, 1984, Norris \& Fenical 1982, Hay \& Goertemiller 1983, Morrison 1984b, Lewis 1985, Paul \& Hay 1986, de Ruyter van Steveninck \& Breeman unpubl.) probably are the results of geographical, habitat or individual variation in plant defenses and/or of differences in herbivore guild composition (Lewis 1985 ) as well as the availability of other, more palatable algal species.

Lobophora variegata does not fit into the functionalform groups as proposed by Littler et al. (1983a, b), who placed this species in the thick-leathery group on the basis of its morphology and productivity studies. Species belonging to this group should show low productivity combined with low losses to grazing. However, Littler et al. (1983a, b) did not test the susceptibility of $L$. variegata to grazing. In their productivity studies these authors found low productivity values for a shallow-water form, which probably differs in morphology from the deep-water form in the present study (cf. Norris \& Bucher 1982). Smith (1981), however, also found low productivity values in a deep water form of L. variegata in North Carolina.

Thus, at Curaçao, Lobophora variegata, a foliose macroalga, which can be distinct in the deep coral reef, has an opportunistic strategy of reducing grazing losses, namely by maintaining growth rates high enough to compensate for these losses (Littler \& Littler 1980, Littler et al. 1983b). The apparently rather constant cover of L. variegata (e.g. at HB, Fig. 5a) is, in fact, the result of a very dynamic balance between growth and (grazing) losses with turnover rates being very high.

Only detailed analyses of growth rates and longevity of individual plants can elucidate these kinds of pro- cesses, knowledge of which is indispensable in understanding community organization.

Acknowledgements. We thank the director and staff of the Caribbean Marine Biological Institute, Curaçao, for working facilities and especially O. Frans, F. Isabella and A. Tiel for diving assistance. Global radiation data were kindly made available by A. J. Dania (Meteorological Service Curaçao). The Buoy 1 transect data were provided by L. L. van Mulekom. Prof. Dr. C. van den Hoek and L. L. van Mulekom critically read the manuscript: this is gratefully acknowledged. The first author was supported by a grant from the Netherlands Foundation for the Advancement of Tropical Research (WOTRO) W84-201

\section{LITERATURE CITED}

Adey, W. H., Adey, P. J., Burke, R., Kaufman, L. (1977). The Holocene reef systerns of Eastern Mártinique. Atoll Res. Bull. 218: 1-40

Bach, S. D. (1979). Standing crop, growth, and production of calcareous siphonales (Chlorophyta) in a south Florida lagoon. Bull. mar. Sci. 29: 191-201

Bak, R. P. M., Carpay, M. J. E., Ruyter van Steveninck, E. D. de (1984). Densities of the sea urchin Diadema antillarum before and after mass mortalities on the coral reefs of Curaçao. Mar. Ecol. Prog. Ser. 17: 105-108

Bernatowicz, A. J. (1952). Seasonal aspects of the Bermuda algal flora. Pap. Mich. Acad. Sci. 36: 3-8

Borowitzka, M. A. (1981). Algae and grazing in coral reef ecosystems. Endeavour, N. Se. 5: 99-106

Brawley, S. H., Adey, W. H. (1977). Territorial behavior of threespot damselfish (Eupomacentrus planifrons) increases reef algal biomass and productivity. Environ. Biol. Fish. 2: 45-51

Carpenter, R. C. (1981). Grazing by Diadema antillarum (Philippi) and its effects on the benthic algal community (1981). J. mar. Res. 39: 749-765

Croley, F. C.. Dawes, C. J. (1970). Ecology of the algae of a Florida Key. I. A preliminary checklist, zonation, and seasonality. Bull. mar. Sci. 20: 165-185

Dawes, C. J., Mathieson, A. C., Cheney, D. P. (1974). Ecological studies of floridian Eucheuma (Rhodophyta, Gigartinales). I. Seasonal growth and reproduction. Bull. mar. Sci 24: $235-273$

Dawes, C. J., Van Breedveld, J. F. (1969). Memoirs of the Hourglass Cruises. Vol. I, Part II: Benthic marine algae. Mar. Res. Lab. St. Petersburg, Florida, p. 1-47

Earle, S. A. (1969). Phaeophyta of the Eastern Gulf of Mexico. Phycologia 7: 71-254

Earle, S. A. (1972). The influence of herbivores on the marine plants of Great Lameshur Bay, with an annotated list of plants. In: Colette, B. B., Earle, S. A. (ed.) Results of the Tektite program: ecology of coral reef fishes. Natural History Museum, Los Angeles County, Sci. Bull. 14: 17-44

Gaines, S. D., Lubchenceo, J. (1982). A unified approach to marine plant-herbivore interactions. II. Biogeography. Ann. Rev. Ecol. Syst. 13: 111-138

Harper, J. L. (1977). Population biology of plants. Academic Press, London

Hatcher, B. G. (1981). The interaction between grazing organisms and the epilithic algal community of a coral reef: a quantitative assessment. Proc. 4th Int. Coral Reef Symp., Manila, Vol. 2: 515-524 
Hay, M. E. (1981). Spatial patterns of grazing intensity on a Caribbean barrier reef: herbivory and algal distribution. Aquat. Bot. 11: 97-109

Hay, M. E. (1984). Predictable spatial escapes from herbivory: how do these affect the evolution of herbivore resistance in tropical marine communities? Oecologia (Berl.) 64: 396-407

Hay, M. E., Goertemiller, T. (1983). Between-habitat differences in herbivore impact on Caribbean coral reefs. In: Reake, M. L. (ed.) The ecology of deep and shallow coral reefs. Symposia Series for Undersea Research, Vol. 1. NOAA, Rockville, Maryland, p. 97-102

Hay, M. E., Norris, J. N. (1984). Seasonal reproduction and abundance of six synpatric species of Gracilaria (Gracilariacea: Rhodophyta). Hydrobiologia 116/117: 63-72

Hay, M. E., Taylor, R. (1985). Competition between herbivorous fishes and urchins on Caribbean reefs. Oecologia (Berl.) 65: 591-598

Hoek, C. van den, Breeman, A. M., Bak, R. P. M., Buurt, G. van (1978). The distribution of algae, corals and gorgonians in relation to depth, light attenuation, water movement and grazing pressure in the fringing coral reef of Curaçao, Netherlands Antilles. Aquat. Bot. 5: 1-46

Hoek, C. van den, Cortel-Breeman, A. M., Wanders, J. B. W. (1975). Algal zonation in the fringing coral reef of Curaçao, Netherlands Antilles, in relation to zonation of corals and gorgonians. Aquat. Bot. 1: 269-308

Josselyn, M. N. (1977). Seasonal changes in the distribution and growth of Laurencia poitei (Rhodophyceae, Ceramiales) in a subtropical lagoon. Aquat. Bot. 3: 217-229

Kaliaperumal, N., Kalimuthu, S. (1976). Changes in growth, reproduction, alginic acid and mannitol contents of Turbinaria decurrens Bory. Botanica mar. 19: 161-178

Lewis, S. M. (1985). Herbivory on coral reefs: algal susceptibility to herbivorous fishes. Oecologia (Berl.) 65: 370-375

Liddel, W. D., Ohlhorst, S. L. (1986). Changes in benthic community composition following the mass mortaily of Diadema at Jamaica. J. exp. mar. Biol. Ecol. 95: 271-278

Littler, M. M., Littler, D. S. (1980). The evolution of thallus form and survival strategies in benthic marine macroalgae: field and laboratory tests of a functional form model. Am. Nat. 116: 25-44

Littler, M. M., Littler, D. S. (1984). Models of tropical reef biogenesis: the contribution of algae. In: Round, F. E., Chapman, D. J. (ed.) Progress in phycological research, Vol. 3. Biopress Ltd., Bristol, p. 323-364

Littler, M. M., Littler, D. S. (1985). Nondestructive sampling. In: Littler, M. M., Littler, D. S. (ed.) Handbook of phycological methods. Ecological field methods: Macroalgae. Cambridge University Press, Cambridge, p. 161-175

Littler, M. M., Littler, D. S., Taylor, P. R. (1983a). Evolutionary strategies in a tropical barrier reef system: functional-form groups of marine macroalgae. J. Phycol. 19: 229-237

Littler, M. M., Taylor, P. R., Littler, D. S. (1983b). Algal resistance to herbivory on a Caribbean barrier reef. Coral Reefs 2: 111-118

Mathieson, A. C., Dawes, C. J. (1975). Seasonal studies of Florida sublittoral marine algae. Bull. mar. Sci. 25: 46-65

Morrison, D. (1984a). Seasonality of Batophora oerstedi (Chlorophyta), a tropical macroalga. Mar. Ecol. Prog. Ser. 14: $235-244$

Morrison, D. (1984b). Mass mortality of Diadema antillarum on a Jamaican coral reef: effect on the algal community. Advances in Reef Science, RSMAS, Miami, p. 85-86

Norris, J. N., Bucher, K. E. (1982). Marine algae and seagrasses from Carrie Bow Cay, Belize. In: Rützler, K., Macintyre, I. G. (ed.) The Atlantic Barrier Reef ecosystem at Carrie Bow Cay, Belize. Smithson. Contr. mar. Sci. 12: $167-238$

Norris, J. N., Fenical, W. (1982). Chemical defense in tropical marine algae. In: Rützler, K., Macintyre, I. G. (ed.) The Atlantic Barrier Reef ecosystem at Carrie Bow Cay, Belize. Smithson. Contr. mar. Sci. 12: 417-431

Ogden, J. C. (1976). Some aspects of herbivore-plant relationships on Caribbean reefs and seagrass beds. Aquat. Bot. 2: 103-116

Ogden, J. C., Brown, R. A., Salesky, N. (1973). Grazing by the echinoid Diadema antillarum Philippi: formation of halos around West Indian Patch reefs. Science 182: 715-717

Ogden, J. C., Lobel, P. S. (1978). The role of herbivorous fishes and urchins in coral reef communities. Environ. Biol. Fish. 3: $49-63$

O'Neal, S. W., Prince, J. S. (1982). Relationship between seasonal growth, photosynthetic production and apex mortality of Caulerpa paspaloides (Chlorophyceae). Mar. Biol. 72: 61-67

Paul, V. J., Hay, M. E. (1986). Seaweed susceptibility to herbivory: chemical and morphological correlates. Mar. Ecol. Prog. Ser. 33: 255-264

Peckol, P. (1982). Seasonal occurrence and reproduction of some marine algae of the continental shelf, North Carolina. Botanica mar. 25: 185-190

Peckol, P., Searles, R. B. (1983). Effects of seasonality and disturbance on population development in a Carolina continental shelf community. Bull. mar. Sci. 33: 67-86

Peckol, P., Searles, R. B. (1984). Temporal and spatial patterns of growth and survival of invertebrate and algal populations of a North Carolina continental shelf community. Estuar. coast. Shelf Sci. 18: 133-143

Prince, J. S. (1980): The ecology of Sargassum pteropleuron Grunow (Phaeophyceae, Fucales) in the waters off South Florida. II. Seasonal photosynthesis and respiration of $S$. pteropleuron and comparison of its phenology with that of S. polyceratium Montagne. Phycologia 19: 190-193

Prince, J. S., O'Neal, S. W. (1979). The ecology of Sargassum pteropleuron Grunow (Phaeophyceae, Fucales) in the waters off South Florida. I. Growth, reproduction and population structure. Phycologia 18: 109-114

Rama Rao, K. (1970). Studies on growth cycle and phycocolloid content in Hypnea musciformis (Wulf) Lamour. Botanica mar. 13: 163-165

Randall, J. E. (1961). Overgrazing of algae by herbivorous marine fishes. Ecology 42: 812

Ruyter van Steveninck, E. D. de, Bak, R. P. M. (1986). Changes in abundance of coral reef bottom components related to mass mortality of the sea urchin Diadema antillarum. Mar. Ecol. Prog. Ser. 34: 87-94

Sachs, L. (1982). Applied statistics. A handbook of techniques. Springer Verlag, New York

Sears, J. R., Wilce, R. T. (1975). Sublittoral, benthic marine algae of southern Cape Cod and adjacent islands: seasonal periodicity, associations, diversity and floristic composition. Ecol. Monogr. 45: 337-365

Smith, W. O., Jr. (1981). Photosynthesis and productivity of benthic macroalgae on the North Carolina continental shelf. Botanica mar. 24: 279-284

Sokal, R. R., Rohlf, F. J. (1981). Biometry, 2nd edn. W. H. Freeman and Co., San Francisco

Stephenson, T. A., Stephenson, A. (1972). Life between tidemarks on rocky shores. W. H. Freeman Co., San Francisco

Tsuda, R. T. (1972). Marine benthic algae of Guam. I. Phaeophyta. Micronesica 8: 87-115

Tsuda, R. T. (1974). Seasonal aspects of the Guam Phaeophyta 
(brown algae). Proc. 2nd Int. Coral Reef Symp. 1. Great Barrier Reef Committee, Brisbane, p. 43-47

Tsuda, R. T., Kami, H. T. (1973). Algal succession on artifical reefs in a marine lagoon environment in Guam. J. Phycol. 9: $260-264$

Umamaheswara Rao, M. (1969). Seasonal variations in growth, alginic acid and mannitol contents of Sargassum wigthii and Turbinaria conoides from the Gulf of Mannar, India. Proc. 6th Int. Seaweed Symp.: 579-584

Umamaheswara Rao, M. Kalimuthu, S. (1972). Changes in mannitol and alginic acid contents of Turbinaria ornata (Turner) J. Agardh in relation to growth and fruiting. Botanica mar. 15: 57-59

This article was submitted to the editor; it was accepted for printing on December 8,1986 